Bull. Fac.Agric.,Cairo Univ., 62:107-117(2011).

\title{
MOBILITY OF DIFFERENT FORMS OF COBALT, NICKEL, CADMIUM AND LEAD IN A CALCAREOUS SANDY SOIL AS AFFECTED BY ORGANIC WASTE APPLICATIONS
}

(Received:10.11.2010)

\author{
By \\ M. I. Al - Wabel \\ Department of Soil Science, Faculty of Food Sciences \& Agriculture, \\ King Saud University, Riyadh, Saudi Arabia
}

\begin{abstract}
The leachability as well as the distribution of chemical forms of cadmium (Cd); nickel (Ni); Cobalt $(\mathrm{Co})$ and lead $(\mathrm{Pb})$ was studied in repacked $15 \mathrm{~cm}$ - calcareous soil columns. The hypotheses tested were that the organic wastes will influence the metal movement, and this will be increased with increasing heavy metal concentration in the applied contaminated water. The different types of organic wastes were thoroughly mixed with the upper $5 \mathrm{~cm}$ depth of soil columns at the rate of thirty ton $\mathrm{ha}^{-1}$. Soil columns were subjected to the intermittent leaching for seven times (eight day intervals) using water containing variable concentrations $(0-400 \mathrm{ppm})$ from the studied heavy metals. After the $7^{\text {th }}$ leachate, each soil column was sampled at five subsequent depths. Results indicated that the soluble forms of Cobalt were found in significantly higher concentrations in the leachates collected underneath the columns, especially at its higher concentrations in the applied contaminated water. Furthermore, Cobalt was found in the leachates at high concentrations due to the organic treatments. On the other hand the total concentrations of the $\mathrm{Co}, \mathrm{Cd}, \mathrm{Ni}$, and $\mathrm{Pb}$ were significantly higher in the organic treatments than the control down to 5 $\mathrm{cm}$ depth, compared to the untreated ones. The calculated mobility index indicated that the elution of the studied heavy metals was enhanced by treating the soil with cow manure; chicken manure; plant compost and $\mathrm{Al}$ Bustan manures, compared to the untreated ones. Obviously, the most extracted metals were attained at $0-2.5 \mathrm{~cm}$ depth of the untreated soil. On the contrary, values of extractable elements from the lower depths of the untreated soils were very low compared to organic treated ones. Data reveal that the solid - phase chemical forms of each metal exhibited widely different patterns depending upon the fraction type, soil depth, and /or the type of organic treatment. The results suggest the adverse environmental implications that may exist in conditions that include high heavy metals contaminated water, calcareous sandy soils and elevated rates of applied organic wastes. Among the studied heavy metals only Cobalt concentrations in the leachates showed potential environmental significance, due to its relatively poor retention by the organic wastes solid phase.
\end{abstract}

Key words: bio- solids, calcareous sandy soil, heavy metals, mobility index, organic wastes, sequential extraction.

\section{INTRODUCTION}

Increasing waste production in Saudi Arabia has increased the problem of how to get rid of it without causing undesirable impact on the environment and human health. Land application of bio-solids and industrial wastes can significantly increase heavy metal concentrations in agricultural soils (Bell et al.(1991); McBride(1995); McBride, et al.(1997); Sloan et al.(1997);Lena, and Gade (1997); Tania et al.,(2003); Halim et al.,(2003); Qiao, et al., (2003)and Lucho-Constantino et al.,(2005) Moreover heavy metals are associated with various soil components in different ways and these associations indicate their mobility in soils as well as their bioavailability (Ahumada et al., 1999). The degree of metal association with different chemical forms depends on soil properties such as $\mathrm{pH}$, organic matter, redox condition, and soil texture (Tagwira et al., 1993). Sanchez-Martin and Sanchez -Camazano (1993) in their study concluded that $\mathrm{Cd}$ was slightly mobile in $27 \%$, moderately mobile in $14 \%$, mobile in $41 \%$ and highly mobile in $18 \%$ of the soils. They further reported that the $\mathrm{pH}$, exchangeable bases, and clay content of soil have a significant effect on Cd mobility. The traditionally held view 
on the migration of heavy metals in organic wastes-amended soils is that the movement of heavy metals is insignificant and, thus, metals remain at the site of its input; i.e. in the topsoil. Field studies have generally shown no difference in heavy metals concentration below $30 \mathrm{~cm}$ between treated and untreated soils with bio-solids (Dowdy and Volk, 1983:and Williams et al., 1985). However, leaching of some heavy metals to $60 \mathrm{~cm}$ depth can occur when large amounts of liquid sewage sludge are applied (Robertson et al., 1982). Banks et al.(2006) studied the leaching and deduction of chromium in a soil affected by soil organic content and reported that the addition of $\mathrm{OM}$ had the strongest influence on chromium mobility. Furthermore, in column leaching studies, it has been shown by many workers that heavy metals can leach through many tens of centimeters of soil (Giusquiani et al., 1992; Antoniadis and Alloway, 2002 and Ashworth, and Alloway.2004.). Attention has also been focused on the leachability of metals from sludge 'products', such as dewatered or composted sludge (Richards et al., 2000 and Gove et al., 2001). According to Elliot and Denny (1982), the addition of organic rich waste such as municipal sludge and industrial wastes can provide enough organic matter to the soils to bind toxic heavy metals like $\mathrm{Cd}, \mathrm{Zn}$, and $\mathrm{Pb}$. Moreover, large numbers of articles on heavy metal concentration in agricultural soils can be found in the literature, however, elemental background or reference values in uncultivated soil are limited (Chen $e t$ al., 1991; Ma et al., 1997; Navas and Lindhorfer, 2002 and Pilar, et al., 2006.). It has been generally assumed that since heavy metals are strongly bound by the soil, leaching of metals downward into ground water is not an environmental issue. Although, in recent years, this assumption is challenged and metal leaching from sludge treated soil has been observed in several studies. However, knowledge on this topic is scarce with little information available under the conditions of Saudi Arabia.

The present work was carried out with the objective to evaluate leachability as well as the contamination degree of heavy metals and their mobility due to organic waste applications. The chemical forms of the solid-phase metals in different soil segments of the treated organic wastes were evaluated using sequential extraction technique.

\section{MATERIALS AND METHODS}

A factorial laboratory soil column experiment was carried out in Feb. 2008, using calcareous sandy soil collected from the Agricultural Experiment Station of the Faculty of Food Sciences and Agriculture, King Saud University, Saudi Arabia.. PVC columns of $5 \mathrm{~cm}$ internal diameter and $20 \mathrm{~cm}$ length with an end cap drilled for an outlet were used in this study. Each column was filled with the collected soil and packed ten times from a height of $10 \mathrm{~cm}$ to obtain a final height of soil in each column to $15 \mathrm{~cm}$ with an approximately bulk density of $1.65 \mathrm{~g} \mathrm{~cm}^{-3}$. Four types of organic manures were used in this study. They were:1) Treated Sludge (Al-Bustan) - Biosolid; 2) Cow dung manure from a dairy farm unrecompensed; 3) Chicken manure ; and 4) Natural organic plant compost. Each of the organic waste was thoroughly mixed with the upper $5 \mathrm{~cm}$ depth of soil in each column at the rate of 30 ton $\mathrm{ha}^{-1}$. Table (1) shows the chemical composition of the used organic wastes.

Soil columns were arranged in a completely randomized block design with three replicates. Thereafter, the soil columns were subjected to the

Table (1): *Chemical constitutes of the tested organic wastes.

\begin{tabular}{|c|c|c|c|c|c|c|c|c|c|c|c|c|c|c|}
\hline \multirow{2}{*}{$\begin{array}{c}\text { Organic } \\
\text { waste }\end{array}$} & O.C & $\mathbf{N}$ & \multirow{2}{*}{$\begin{array}{l}\mathrm{C} / \mathrm{N} \\
\text { ratio }\end{array}$} & $\mathbf{N}$ & $\mathbf{P}$ & $\mathbf{K}$ & $\mathbf{F e}$ & Mn & $\mathbf{Z n}$ & $\mathbf{C u}$ & Cd & Co & $\mathbf{N i}$ & $\mathbf{P b}$ \\
\hline & \multicolumn{2}{|c|}{$\%$} & & \multicolumn{3}{|c|}{$\%$} & \multicolumn{8}{|c|}{ mg.kg ${ }^{-1}$} \\
\hline $\begin{array}{c}\text { Al Bustan } \\
\text { manure } \\
\text { (Bio- } \\
\text { solids) }\end{array}$ & 26.65 & 1.34 & 19.9 & 1.34 & 0.64 & 0.51 & 692.5 & 6.5 & 12 & 15.9 & 0.2 & 0.4 & 1.2 & 0.34 \\
\hline $\begin{array}{c}\text { Cow } \\
\text { manure }\end{array}$ & 33.53 & 1.68 & 20.0 & 1.68 & 0.53 & 0.63 & 698.9 & 11.5 & 46.6 & 14.9 & 0.2 & 0.2 & 3.6 & 0.84 \\
\hline $\begin{array}{l}\text { Chicken } \\
\text { manure }\end{array}$ & 19.43 & 1.23 & 15.8 & 1.43 & 1.02 & 1.32 & 79.5 & 22.3 & 21.2 & 11 & 0.2 & 0.4 & 3 & 0.78 \\
\hline $\begin{array}{c}\text { Plant } \\
\text { compost }\end{array}$ & 28.2 & 1.43 & 19.7 & 1.23 & 0.43 & 0.55 & 987.6 & 22.9 & 59.4 & 29.1 & 0.3 & 0.2 & 1.6 & 0.82 \\
\hline
\end{tabular}

*According to the methods described by Page et al. (1982); and Hossner (1996). 
intermittent leaching for seven times (eight day intervals). The leaching was performed by adding an amount of contaminated water equivalent to $130 \%$ of the field capacity on top of each column. The leaching water was contaminated with $\mathrm{Co}, \mathrm{Ni}$, $\mathrm{Cd}$, and $\mathrm{Pb}$, as $\mathrm{NO}_{3}$ salts in concentration of 0,25 , $50,100,200$, and $400 \mathrm{mgl}^{-1}$ according to the treatments .Each leachate was collected and analyzed for its content of the studied heavy metals After the $7^{\text {th }}$ leachate, each soil column was sampled at five subsequent depths, i.e., 02.5, 2.5-5.0, 5.0-7.5, 7.5-10 and 10-15 cm from top to bottom, respectively. The soil of each depth was air dried ground, thoroughly mixed and stored for the chemical analyses. Also, the sequential extraction procedure as described by Kabala and. Singh (2001) and Kashem and Singh, (2002) used to estimate the chemical forms of the studied metals in six steps as shown in Table (2). Following extractions the content of the studied metals in the solutions were determined by the ICP (Perkin Elmer, Model 4300 DV). Also, the mobility indexes as well as, the amount of extracted metals in each fraction, as a percentage of total metal content, were calculated as follows: The mobility index $=\left(\sum\right.$ (mobile forms) $/ \sum$ (immobile forms); i.e. $\sum(\mathrm{F} 1+\mathrm{F} 2+\mathrm{F} 3) / \sum$ (F4+F5+F6) according to Kashem and Singh, (2002). The obtained data were statistically analyzed according to Snedecor and Cochran, (1973).
$\mathrm{CaCO}_{3}$ ) and sandy in texture, having Ec values less than $4 \mathrm{dS} \mathrm{m}^{-1}$ and $\mathrm{pH}$ of 8.22 and $0.51 \%$ organic matter content. The most dominant cations in that soil are $\mathrm{Na}^{+} ; \mathrm{Ca}^{2+}$ and $\mathrm{Mg}^{2+}$ meanwhile the chlorides and bicarbonates are the most dominant anions. The C.E.C is $9.93 \mathrm{Cmolkg}^{-1}$. also the total concentrations of heavy metals in that soil were $44.3 ; 10.7 ; 3.1 ; 1.6 ; 1.2 ; 2.11$ and 1.5 $\mathrm{mg} \mathrm{kg}{ }^{-1}$ for $\mathrm{Mn} ; \mathrm{Zn} ; \mathrm{Cu}$; $\mathrm{Cd}$; $\mathrm{Co}$; $\mathrm{Ni}$; and $\mathrm{Pb}$, respectively (Tables $3 \mathrm{~A} ; 3 \mathrm{~B}$ and $3 \mathrm{C}$ ).

\subsection{Effect of the experimental treatments on the leachability of heavy metals}

Based on leachate concentrations as shown in Table (4), Cobalt was the only element to behave in a potentially environmentally significant way. Its relatively high degree of solubility in the organic wastes suggests that soil leachate concentrations may be of concern in situations where high concentrations of such metal are applied with water to soil columns. The application of organic wastes resulted in increasing the leachability of the Co from calcareous soil columns, as the soluble forms of Co was found in significantly higher concentrations due to the higher application rates of such metals in the applied contaminated water. Moreover, such metal was found in the leachates at high concentrations affecting by the organic waste treatments. This indicates that bio- solids of organic fractions might have played a significant role in facilitating soluble Co transport down the

Table ( 2): The sequential extraction procedure used for extracting forms of the studied heavy metals.

\begin{tabular}{|c|c|c|c|}
\hline Step & Fraction & $\begin{array}{l}2 \mathrm{~g} \text { soil sample from each depth was sequentially extracted } \\
\text { with }\end{array}$ & $\begin{array}{l}\text { Centrifuge/ } \\
\text { filtrate }\end{array}$ \\
\hline 1 & $\begin{array}{l}\text { F1- Water } \\
\text { soluble }\end{array}$ & $20 \mathrm{ml}$ DI water for $1 \mathrm{~h}$ at $25 \mathrm{C}^{\circ}$ - Rolling table & $\begin{array}{l}10000 \mathrm{rpm}, \text { in } \\
30 \mathrm{~min}\end{array}$ \\
\hline 2 & $\begin{array}{l}\text { F2- } \\
\text { Exchangeable }\end{array}$ & $20 \mathrm{ml} 1 \mathrm{M} \mathrm{NH}_{4} \mathrm{OAC}(\mathrm{pH} 7)$ for $2 \mathrm{~h}$ at $25 \mathrm{C}^{\circ}$ - Rolling table & $\begin{array}{l}\text { 10000rpm, in } 30 \\
\text { min }\end{array}$ \\
\hline 3 & $\begin{array}{l}\text { F3- Carbonate } \\
\text { bond }\end{array}$ & $20 \mathrm{ml} 1 \mathrm{M} \mathrm{NH}_{4} \mathrm{OAC}(\mathrm{pH} 5)$ for $2 \mathrm{~h}$ at $25 \mathrm{C}^{0}$ - Rolling table & $\begin{array}{l}\text { 10000rpm, in } 30 \\
\text { min }\end{array}$ \\
\hline 4 & $\begin{array}{l}\mathrm{F} 4-\mathrm{Fe} \text { and } \\
\text { Mn Oxide bond }\end{array}$ & $\begin{array}{l}20 \mathrm{ml} 0.04 \mathrm{M} \mathrm{NH} \mathrm{N}_{2} \mathrm{OH} . \mathrm{HCl} \text { in } 25 \%(\mathrm{v} / \mathrm{v}) \mathrm{Ace}(\mathrm{pH} 3) \text { for } 6 \mathrm{~h} \text { at } \\
80 \mathrm{C}^{\mathrm{o}} \text { - shaking water bath }\end{array}$ & $\begin{array}{l}\text { 10000rpm, in } 30 \\
\text { min }\end{array}$ \\
\hline 5 & $\begin{array}{l}\text { F5- Organically } \\
\text { bond }\end{array}$ & $\begin{array}{l}15 \mathrm{ml} 30 \% \mathrm{H}_{2} \mathrm{O}_{2}(\operatorname{adj~pH} 2) \text { for } 5.5 \mathrm{~h} \text { at } 80 \mathrm{C}^{\circ} \text { and } 5 \mathrm{ml} 3.2 \mathrm{M} \\
\mathrm{NH}_{4} \text { OAcet } 25 \mathrm{C}^{\mathrm{o}} \text { in } 20 \%(\mathrm{v} / \mathrm{v}) \mathrm{HNO}_{3} \text {, shaking water bath and } \\
\text { rolling table. }\end{array}$ & $\begin{array}{l}\text { 10000rpm, in } 30 \\
\min \end{array}$ \\
\hline 6 & F6- Residual & $7 \mathrm{M} \mathrm{HNO}_{3}$ for $6 \mathrm{~h}$ at $80 \mathrm{C}^{\circ}$ & filtrate \\
\hline
\end{tabular}

\section{RESULTS AND DISCUSSION}

\subsection{Characteristics of the studied soils}

According to the soil Survey Staff (1999) the soil used in this study is characterized by Typic Torriorthents .Such soil is calcareous $(25.0 \%$ soil profile. Moreover cobalt concentrations were increased with increasing the leachate number (Fig.1). This was more pronounced especially at the higher levels of Co in water application. 
Table (3): Physical and chemical properties of the investigated soils.

3A) Physical properties*

\begin{tabular}{|c|c|c|c|c|c|c|c|}
\hline \multicolumn{3}{|c|}{ Particle size distribution $\%$} & \multirow{2}{*}{$\begin{array}{c}\text { Texture } \\
\text { class }\end{array}$} & \multirow{2}{*}{$\begin{array}{c}\text { Field capacity } \\
\%\end{array}$} & \multirow{2}{*}{$\begin{array}{c}\text { Wilting point } \\
\%\end{array}$} & \multirow{2}{*}{$\begin{array}{l}\text { Available } \\
\text { water } \%\end{array}$} & \multirow{2}{*}{$\begin{array}{c}\mathrm{CaCO}_{3} \\
\% \\
\end{array}$} \\
\hline Sand & Silt & Clay & & & & & \\
\hline 90.1 & 2.0 & 7.9 & Sandy & 12.41 & 6.42 & 5.99 & 25.0 \\
\hline
\end{tabular}

3B): Chemical properties*

\begin{tabular}{|c|c|c|c|c|c|c|c|c|c|}
\hline \multirow[b]{2}{*}{$\mathrm{pH}$} & \multirow[b]{2}{*}{$\begin{array}{c}\text { Ec } \\
(\mathrm{dS} / \mathrm{m})\end{array}$} & \multicolumn{3}{|c|}{ Soluble cations (meq. $\left.1^{-1}\right)^{*}$} & \multicolumn{3}{|c|}{ Soluble anions (meq..$\left.^{-1}\right)^{*}$} & \multirow{2}{*}{$\begin{array}{c}\text { OM* } \\
\%\end{array}$} & \multirow{2}{*}{$\begin{array}{c}\mathrm{CEC}^{*} \\
\text { Cmol.kg }{ }^{-1}\end{array}$} \\
\hline & & $\begin{array}{l}\left(\mathrm{Ca}^{2+}+\right. \\
\left.\mathrm{Mg}^{2+}\right) \\
\end{array}$ & $\mathrm{Na}^{+}$ & $\mathrm{K}^{+}$ & $\begin{aligned} &\left(\mathrm{CO}_{3}^{-}\right. \\
&+\left.\mathrm{HCO}_{3}^{-}\right) \\
&\end{aligned}$ & $\mathrm{CL}^{-}$ & $\mathrm{SO}_{4}{ }^{2-}$ & & \\
\hline 8.22 & 3.54 & 14.74 & 20.28 & 1.22 & 11.33 & 18.98 & 6.63 & 0.51 & 9.93 \\
\hline
\end{tabular}

3C): Heavy metal concentration

\begin{tabular}{|c|c|c|c|c|c|c|}
\hline \multicolumn{7}{|c|}{ Total concentration $\left(\mathrm{mgkg}^{-1}\right) * *$} \\
\hline $\mathrm{Mn}$ & $\mathrm{Zn}$ & $\mathrm{Cu}$ & $\mathrm{Cd}$ & $\mathrm{Co}$ & $\mathrm{Ni}$ & $\mathrm{Pb}$ \\
\hline 44.3 & 10.7 & 3.1 & 1.6 & 1.2 & 2.11 & 1.5 \\
\hline
\end{tabular}

According to the methods described by* Hossner, (1996) ); and **Page et al.,( 1982).

Table (4): Heavy metal concentration (mg. $\mathrm{I}^{-1}$ ) found in the seven studied leachates as affected by organic wastes application.

\begin{tabular}{|c|c|c|c|c|c|}
\hline \multirow{2}{*}{ Treatments } & \multirow{2}{*}{$\begin{array}{l}\text { Application rate of } \\
\text { heavy metals }\left(\mathrm{mg} \mathrm{l}^{-1}\right)\end{array}$} & \multicolumn{4}{|c|}{$\mathrm{mg} \mathrm{l}^{-1}$} \\
\hline & & $\mathbf{P b}$ & Cd & Co & $\mathbf{N i}$ \\
\hline \multirow{6}{*}{ Control } & 0 & nd & nd & nd & nd \\
\hline & 25 & nd & nd & nd & nd \\
\hline & 50 & nd & nd & nd & nd \\
\hline & 100 & nd & nd & 0.28 & nd \\
\hline & 200 & nd & nd & 5.28 & nd \\
\hline & 400 & nd & nd & 15.11 & nd \\
\hline \multirow{6}{*}{$\begin{array}{l}\text { Al- Bustan } \\
\text { manure }\end{array}$} & 0 & nd & nd & nd & nd \\
\hline & 25 & nd & nd & 0.89 & nd \\
\hline & 50 & nd & nd & 2.19 & nd \\
\hline & 100 & nd & nd & 5.72 & nd \\
\hline & 200 & nd & nd & 16.76 & nd \\
\hline & 400 & nd & nd & 47.83 & nd \\
\hline \multirow{6}{*}{ Cow manure } & 0 & nd & nd & nd & nd \\
\hline & 25 & nd & nd & 0.36 & nd \\
\hline & 50 & nd & nd & 2.27 & nd \\
\hline & 100 & nd & nd & 6.61 & nd \\
\hline & 200 & nd & nd & 19.83 & nd \\
\hline & 400 & nd & nd & 55.68 & nd \\
\hline \multirow{6}{*}{ Plant compost } & 0 & nd & nd & nd & nd \\
\hline & 25 & nd & nd & 0.59 & nd \\
\hline & 50 & nd & nd & 9.35 & nd \\
\hline & 100 & nd & nd & 24.36 & nd \\
\hline & 200 & nd & nd & 36.39 & nd \\
\hline & 400 & nd & nd & 71.61 & nd \\
\hline \multirow{6}{*}{ Chicken manure } & 0 & nd & nd & nd & nd \\
\hline & 25 & nd & nd & 0.2 & nd \\
\hline & 50 & nd & nd & 1.69 & nd \\
\hline & 100 & nd & nd & 10.89 & nd \\
\hline & 200 & nd & nd & 15.71 & nd \\
\hline & 400 & nd & nd & 32.02 & nd \\
\hline
\end{tabular}

nd $=$ not detected or the value is blew the detection limit of the ICP-OES. 


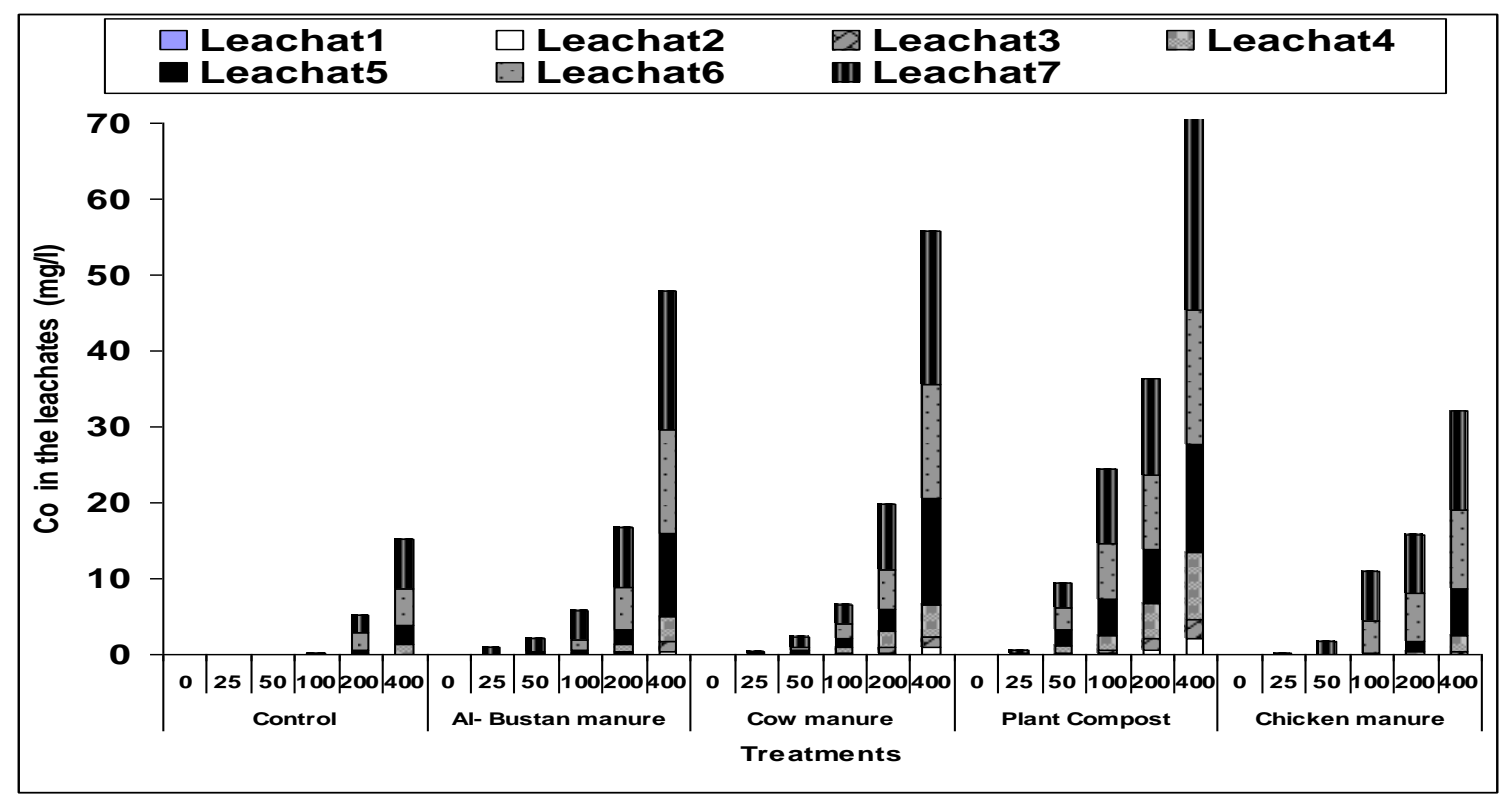

Fig. (1): Leachability of Cobalt, from calcareous soil columns as affected by organic wastes applications.

with plant compost followed by cow manure; $\mathrm{Al}-$ Bustan manure and chicken manure. On the contrary, results showed that there was no measurable impact from the other studying metals $\mathrm{Cd} ; \mathrm{Ni}$ and $\mathrm{Pb}$ following organic wastes applications to the soil. i.e. the application of the organic wastes resulted in increased concentrations and total amounts of $\mathrm{Co}$ in the leachates from the soil, but had little or no effect on the concentrations of, $\mathrm{Cd}, \mathrm{Ni}$, and $\mathrm{Pb}$.

\subsection{Effect of the experimental treatments on the total heavy metal distribution}

Results in Figs (2- 7) showed that Co, Cd, Ni and $\mathrm{Pb}$ remained confined to the upper soil layer of the untreated soil columns. The application of organic wastes resulted in increasing the total concentrations of the studying heavy metals especially in the $0-5 \mathrm{~cm}$ columns depths, followed by a gradual decrease with increasing column depth. The total concentration of heavy metals followed the following descending order: Cow manure $>$ Plant compost $>$ Al Bustan manure $>$ Chicken manure > Control regardless of either soil depth and /or heavy metals concentrations in the applied water (Fig. 2). Such findings were confirmed by the calculations of the mobility index according to Kashem and Singh, (2002). Such index indicated that the elution of $\mathrm{Ni}, \mathrm{Cd}, \mathrm{Pb}$ and $\mathrm{Co}$ was enhanced at the application of organic wastes compared to the control treatment (Fig.3).

In the treated soil, the total concentrations of metals were significantly higher than the control down to a depth of $0-2.5 \mathrm{~cm}$, as the $\mathrm{Co}, \mathrm{Ni}, \mathrm{Cd}$, and $\mathrm{Pb}$ moved to the lower depth (Table, 5).
The most extracted metals form the untreated soil was attained at the $0-2.5 \mathrm{~cm}$ depth. However, at the lower depths of the untreated soils, values of extractable elements were very low compared to organic treated ones (Figs. $4,5,6$ and 7). This indicates that bio- solids of organic fractions might have played a significant role in facilitating soluble $\mathrm{Co}, \mathrm{Ni}, \mathrm{Cd}$, and $\mathrm{Pb}$ transport down the soil profile. Antoniadis and Alloway, (2002) arrived to similar findings for $\mathrm{Cd}, \mathrm{Ni}$ and $\mathrm{Zn}$ movement down the profile of sewage sludge treated soil.

3.4. Effect of the experimental treatments on chemical forms of heavy metals

The surface-application (equivalent to $30 \mathrm{t} \mathrm{ha}^{-}$ $\left.{ }^{1}\right)$ from different types of organic wastes was found to be effective in playing an important role in the mobility of different chemical forms of $\mathrm{Co}, \mathrm{Ni}, \mathrm{Cd}$ and $\mathrm{Pb}$ through the calcareous sandy soil columns (Figs. 8, 9, 10, and 11). The importance of organic wastes in promoting the mobility of the studied heavy metals was evidenced by their higher mobility when added to the calcareous soil column as inorganic forms. That is to say, the application of organic wastes caused an increment in the total amounts of extracted elements especially in the mobile forms (F1- F3, e.g. water soluble, exchangeable and carbonate forms). The water-soluble and the exchangeable fractions of metals were relatively small comparing to the other metal forms. However, the extractable fraction of organically bond $\mathrm{Ni}$ was high compared to the other elements. Generally, the data revealed that the solid - phase chemical 
Table (5): Distribution of the studied heavy metals throughout calcareous soil columns as affected by the applied organic wastes

\begin{tabular}{|c|c|c|c|c|c|}
\hline \multirow[b]{2}{*}{ Treatments } & \multirow[b]{2}{*}{ Soil depth $(\mathrm{cm})$} & \multicolumn{4}{|c|}{ Total concentrations $\left(\mathrm{mg} \cdot \mathrm{kg}^{-1}\right)$} \\
\hline & & $\mathbf{P b}$ & Cd & Co & $\mathbf{N i}$ \\
\hline \multirow{5}{*}{ Control } & $0-2.5$ & 980.1 & 964.2 & 942.8 & 959.5 \\
\hline & $2.5-5.0$ & 34.7 & 33.4 & 40.3 & 33.1 \\
\hline & $5.0-7.5$ & 9.9 & 9.5 & 13.5 & 11.4 \\
\hline & $7.5-10.0$ & 2.6 & 3.5 & 5.8 & 7.5 \\
\hline & $10.0-15.0$ & 1.8 & 1.7 & 3.1 & 4.8 \\
\hline \multirow{5}{*}{$\begin{array}{l}\text { Al Bustan } \\
\text { manure }\end{array}$} & $0-2.5$ & 939.1 & 903.0 & 840.2 & 894.0 \\
\hline & $2.5-5.0$ & 91.2 & 87.7 & 105.8 & 86.8 \\
\hline & $5.0-7.5$ & 15.5 & 14.9 & 18.0 & 14.7 \\
\hline & $7.5-10.0$ & 9.0 & 8.7 & 12.5 & 8.6 \\
\hline & $10.0-15.0$ & 4.8 & 4.6 & 9.6 & 4.6 \\
\hline \multirow{5}{*}{ Cow manure } & $0-2.5$ & 829.0 & 797.1 & 694.9 & 789.2 \\
\hline & $2.5-5.0$ & 213.6 & 205.3 & 247.9 & 203.3 \\
\hline & $5.0-7.5$ & 10.1 & 9.7 & 11.7 & 9.6 \\
\hline & $7.5-10.0$ & 2.0 & 1.9 & 2.3 & 1.9 \\
\hline & $10.0-15.0$ & 2.2 & 2.1 & 2.6 & 2.1 \\
\hline \multirow{5}{*}{ Plant compost } & $0-2.5$ & 862.3 & 829.1 & 426.8 & 820.8 \\
\hline & $2.5-5.0$ & 202.5 & 194.7 & 235.1 & 192.7 \\
\hline & $5.0-7.5$ & 34.7 & 33.3 & 43.3 & 33.0 \\
\hline & $7.5-10.0$ & 16.2 & 15.6 & 28.8 & 15.5 \\
\hline & $10.0-15.0$ & 6.7 & 6.5 & 17.8 & 6.4 \\
\hline \multirow{5}{*}{ Chicken manure } & $0-2.5$ & 908.0 & 873.1 & 570.9 & 864.4 \\
\hline & $2.5-5.0$ & 48.8 & 56.9 & 96.7 & 46.5 \\
\hline & $5.0-7.5$ & 4.8 & 5.5 & 73.8 & 6.4 \\
\hline & $7.5-10.0$ & 3.1 & 3.2 & 35.1 & 4.7 \\
\hline & $10.0-15.0$ & 2.8 & 2.4 & 19.9 & 3.4 \\
\hline \multicolumn{6}{|c|}{ LSD at $5 \%$ level for: } \\
\hline \multicolumn{2}{|l|}{ Organic wastes (A) } & 14.26 & 9.22 & 8.37 & 10.35 \\
\hline \multicolumn{2}{|l|}{ Soil depth (B) } & 14.26 & 9.22 & 8.37 & 10.35 \\
\hline \multicolumn{2}{|l|}{ A X B } & 48.31 & 51.18 & 45.21 & 56.61 \\
\hline
\end{tabular}

forms of each metal in the wastes treated soil exhibited widely different patterns depending upon the fraction type, soil depth, and the type of the applied organic wastes. The calculated mobility index indicated that, the majority of metals were recovered as immobile forms (F4 F6, e.g. oxide, organic, and residual forms) in the untreated soils. While, nearly $50 \%$ of the studied metals in the organic treatments were recovered in the mobile forms (e.g. water soluble, exchangeable and carbonate forms). The distribution of different forms of heavy metals in the untreated soil columns was as follows:

Co: oxide $>$ residual $>$ carbonate $>$ organic $>$ exchangeable $>$ water soluble.

Cd: exchangeable $>$ Carbonate $>$ water soluble $>$ oxide $>$ organic $>$ residual.

Ni: oxide $>$ exchangeable $>$ carbonate $>$ organic $>$ residual $>$ water soluble.

$\mathrm{Pb}$ : carbonate >oxide > exchangeable.> residual $>$ organic > water soluble. Such order could signify a low availability of $\mathrm{Co}$ and $\mathrm{Ni}$ metals to plants, since the readily soluble form of metals is often regarded as the most bio available. However by treating calcareous soil with Al- Bustan manure (for example), the relatively distribution was as follows:

Co: exchangeable $>$ carbonate $>$ water soluble $>$ oxide $>$ organic $>$ residual

Cd: exchangeable. $>$ carbonate $>$ water soluble $>$ organic $>$ oxide $>$ residual.

$\mathrm{Ni}$ : organic $>$ carbonate $>$ exchangeable $>$ water soluble $>$ oxide $>$ residual

$\mathrm{Pb}$ : carbonate $>$ oxide $>$ exchangeable $>$ organic $>$ residual $>$ water soluble. 


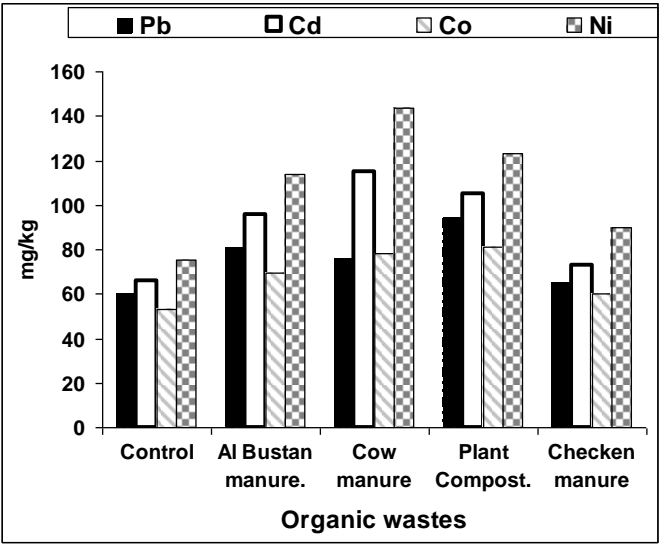

Fig. (2): Effect of organic wastes on the total concentration (mg.kg $\left.{ }^{-1}\right)$ of $\mathrm{Ni}, \mathrm{Co}, \mathrm{Cd}$, and $\mathbf{P b}$ in calcareous soil columns regardless of soil depth.

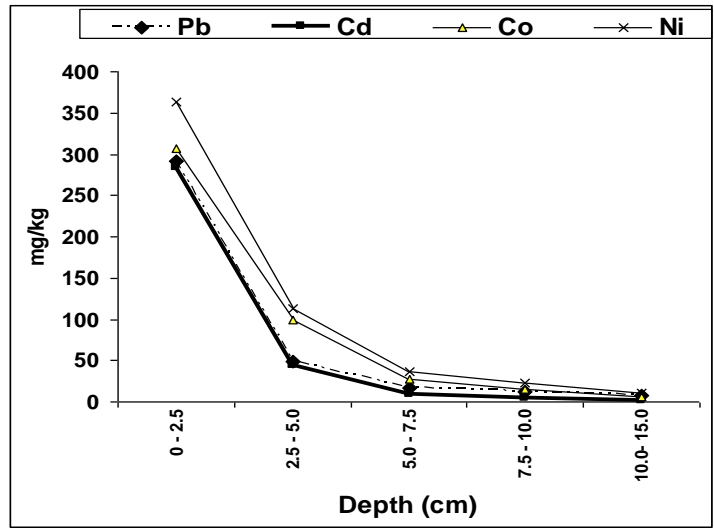

Fig.(4): Distribution(mg.kg $\left.{ }^{-1}\right)$ of $\mathrm{Ni}, \mathrm{Co}, \mathrm{Cd}$ and $\mathrm{Pb}$ throughout soil columns depths regardless of organic wastes applications.

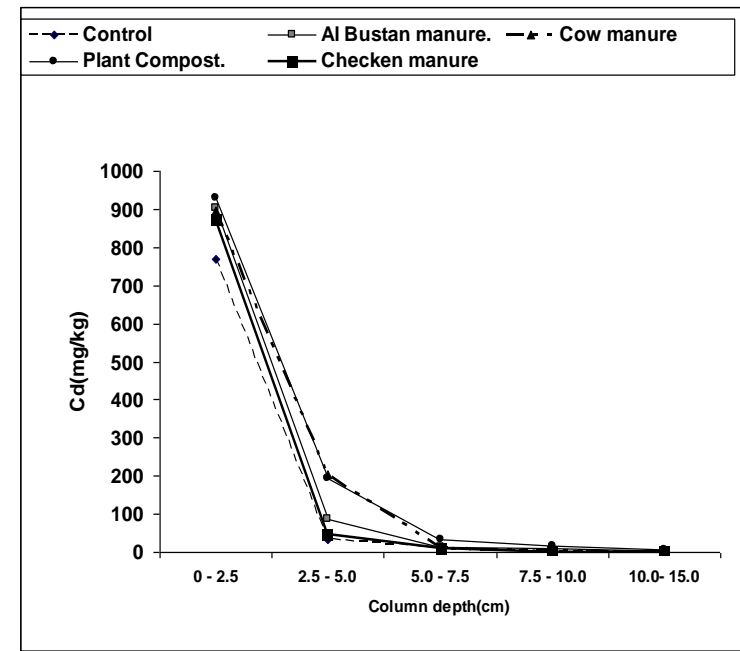

Fig.(6): Distribution(mg.kg $\left.{ }^{-1}\right)$ of cadmium throughout depths of calcareous soil columns as affected by organic wastes applications.

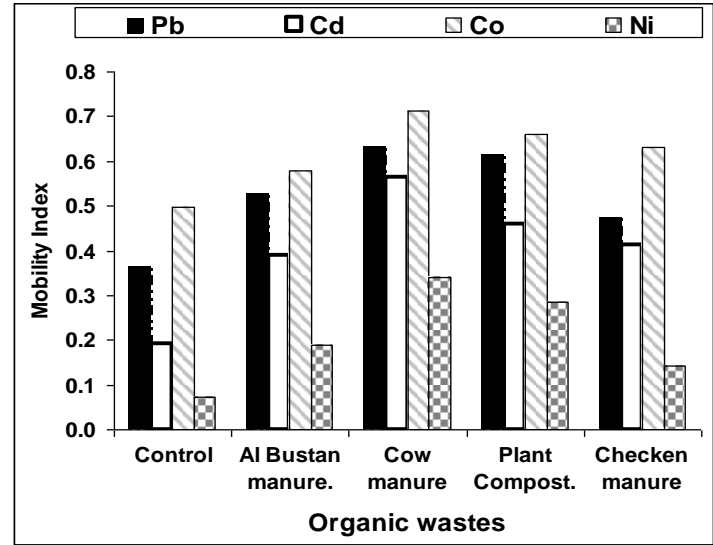

Fig. (3): Mobility index of $\mathrm{Co}, \mathrm{Ni}, \mathrm{Cd}$, and $\mathrm{Pb}$ throughout calcareous soil columns as affected by organic wastes applications.

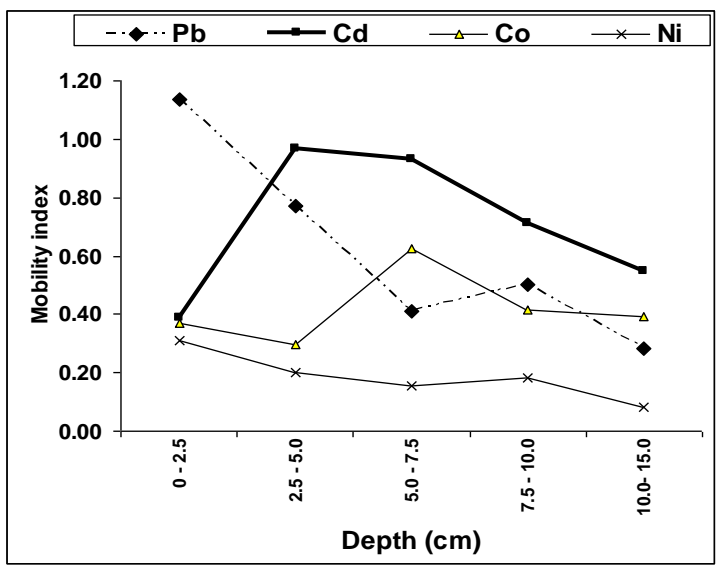

Fig. (5): Mobility index of $\mathrm{Ni}, \mathrm{Co}, \mathrm{Cd}$ and $\mathrm{Pb}$ throughout soil columns depths regardless of organic wastes applications

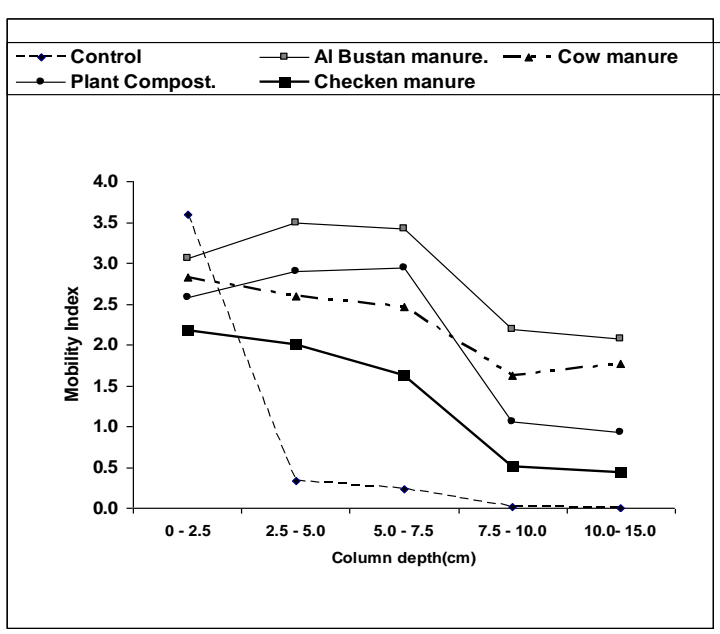

Fig:(7): The mobility index of cadmium throughout depths of calcareous soil columns as affected by organic wastes applications. 


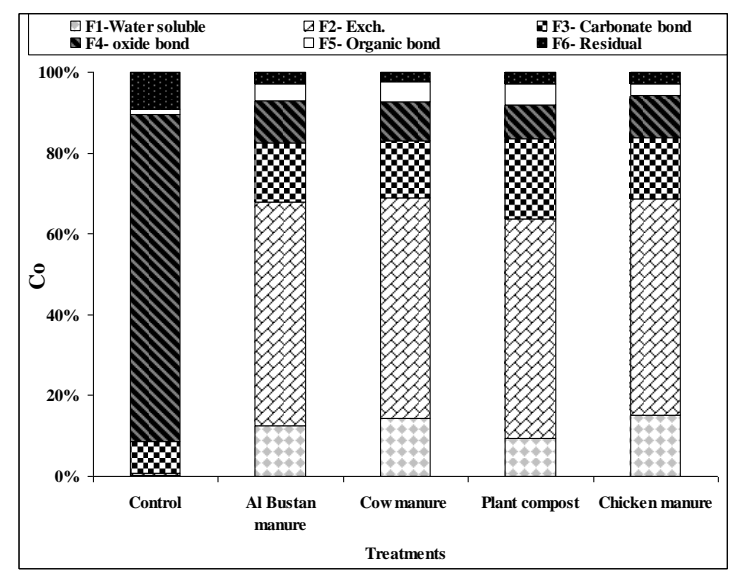

Fig. (8): Distribution of different forms of cobalt (as a percent of the total) in the upper depth $(0-2.5 \mathrm{~cm})$ of calcareous soil as affected by organic wastes applications

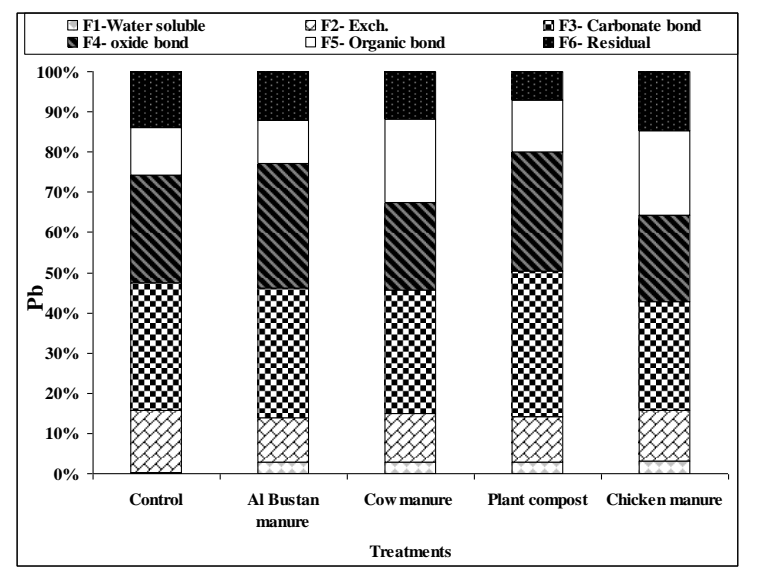

Fig.(10): Distribution of different forms of Lead (as a percentage of the total) in the upper depth $(0-2.5 \mathrm{~cm})$ of calcareous soil as affected by organic wastes applications.

This was true in general for the other applied organic wastes. It appears therefore that, the studied metals could be found in mobile forms affected by treating calcareous sandy soil with organic wastes. It is also obvious that the values of the studied metals extracted with milder reagents $\left(\mathrm{F}_{1}-\mathrm{F}_{3}\right)$ fractions (e.g. water soluble, exchangeable and carbonate forms) increased significantly in the organic wastes treatments. The increase in the solubility of such metals leads to an improvement in their bioavailability. On the other hand, the extractable amounts of $\mathrm{Ni}$, and $\mathrm{Co}$ from the untreated soils were very low in the mobile forms (e.g. water soluble, exchangeable and carbonate

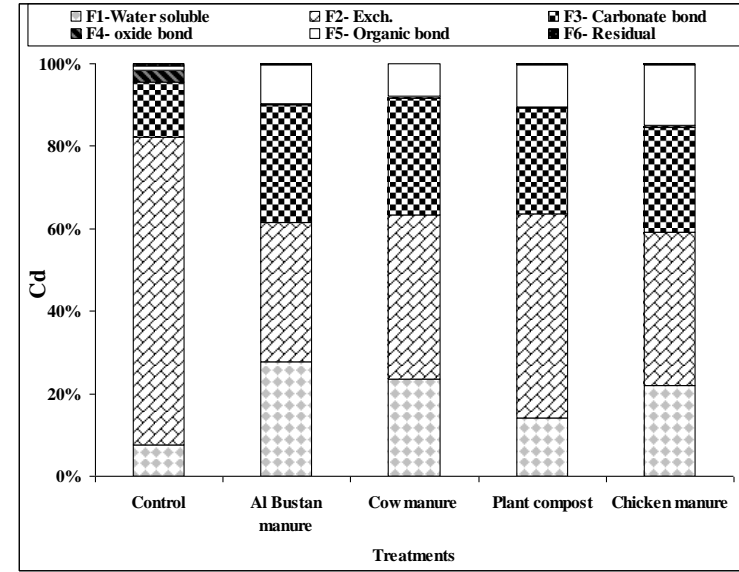

Fig. (9): Distribution of different forms of cadmium (as a percentage of the total) in the upper depth $(0-2.5 \mathrm{~cm})$ of calcareous soil as affected by organic wastes applications.

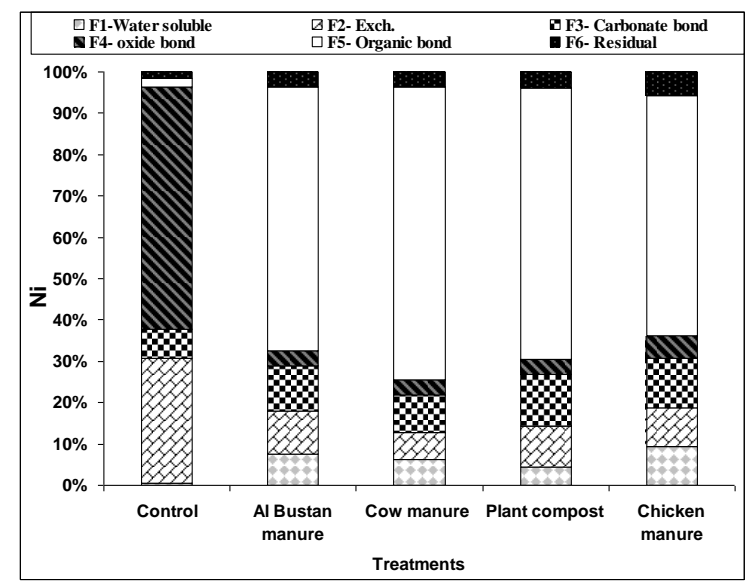

Fig.(11):Distribution of different forms of nickel (as a percentage of the total) in the upper depth $(0-2.5 \mathrm{~cm})$ of calcareous soil as affected by organic wastes applications.

forms), due to the complexes of such metals with soil components (Ahumada et al., 1999). On the other hand, the mobility of $\mathrm{Cd}$; $\mathrm{Co}$ and $\mathrm{Pb}$ is susceptible to the type of applied organic wastes, as the carbonate and exchangeable forms of $\mathrm{Cd}$ were increased in the $\mathrm{Al}$ Bustan and plant compost treatments and hence it may be regarded as potentially phyto-available. In addition, the carbonate form of $\mathrm{Cd}$ is relatively mobile in the other organic waste treatments. Such results agree well with the findings of Kim and Fergusson (1991);Chlopecka (1993) and Kabala, and Singh (2001). On the other hand, most of extracted elements were in the mobile forms (F1- F3, e.g. 
water soluble, exchangeable and carbonate forms. This was true, in general for all studied organic wastes. The water-soluble and the exchangeable fractions of metals were relatively small compared to the other metal forms.

\section{Conclusion}

From the previously given data it can be mentioned that: In the leachates collected underneath the columns cobalt was the only element to behave in a potentially environmentally significant way. Its relatively high degree of solubility due to the organic treatment suggests that soil leachate concentrations may be of concern in situations where high Co contaminated water was applied to calcareous soil. Most of elements were concentrated in the surface layer $(0-2.5)$ of the untreated soils. On the contrary, relatively increases were obtained in total concentrations of $\mathrm{Co}, \mathrm{Cd}$, and $\mathrm{Ni}$ and $\mathrm{Pb}$ at the lower depths of organic wastes treatments. Also, the exchangeable fraction of $\mathrm{Cd}$ was more pronounced; whereas the oxide and carbonate bond were more pronounced for $\mathrm{Ni}$ and $\mathrm{Pb}$ in the organic wastes treatments. On the other hand, the water soluble and exchangeable fractions of metals in the untreated soils, constituted the least proportion of elements fraction. Furthermore, the organic wastes have changed the solid phase containing heavy metals in soils away from those extractable with more severe reagents such as $7 \mathrm{M}$ $\mathrm{HNO}_{3}$, to those extractable with milder reagents as dilute $\mathrm{NH}_{4} \mathrm{OAC}$. This change suggests that organic wastes application would provide the metals in mobile chemical forms that could be readily available to plants than in the untreated soils. The mobile forms $\left(\mathrm{F}_{1}-\mathrm{F}_{3}\right.$ e.g., water soluble, exchangeable and carbonate) of each of the studied metals tend to increase by nearly $30 \%$ of the total metal content in the organic wastes treatments depending upon the type of element and / or the type of applied organic wastes. On the contrary, the immobile forms (F4 - F6 e.g., Fe-Mn oxide, organic and residual forms) of each of the studied metals represents (more than $70 \%$ of the total metal content) in the untreated soils. This could signify a low availability of such metals to plants in the untreated soils, since the readily soluble form of metals is often regarded as the most bioavailability.

\section{REFERENCES}

Ahumada I. , Mendoza J. and Ascar L. (1999). Sequential extraction of heavy metals in soils irrigated with sewage water. Commu. Soil Sci. Plant Anal., 30: 1507-1519.

Antoniadis V. and Alloway B.J. (2002). Leaching of cadmium, nickel and zinc down the profiles of sewage sludge-treated soil. Commuin. Soil Sci. Plant Anal., 33: 273-286.

Ashworth D.J. and Alloway B.J.(2004). Soil mobility of sewage sludge-derived dissolved organic matter, copper, nickel and zinc. Environmental Pollution, 127: 137-144

Banks M.K., Schwab A.P. and Henderson C.(2006). Leaching of chromium in soil as affected by soil organic content and plants. Chemosphere, 62: 255-264.

Bell P.F., James B.R. and Chaney R.L.(1991). Heavy metal extractability in long-term sewage sludge and metal salt-amended soils. J. Environ. Qual., 20: 481-486.

Chen J., Wei F. and Chang C.(1991). Background concentrations of elements in soils of China . Water. Air and Soil Pollution, 57-58:699-712.

Chlopecka A. (1993). Forms of trace metals from inorganic sources in soils and amounts found in spring barley. Water. Air Soil Pollut., 69:127 134.

Dowdy R. H. and Volk V. V. (1983). Heavy metal movement in soils. p. 229-240. In D. W. Nelson et al. (ed.) Chemical mobility and reactivity in soil systems. SSSA Spec. Publ. 11. ASA, CSSA, and SSSA, Madison, WI.

Elliot H. A. and Denny C. M.(1982). Soil adsorption of cadmium from solutions containing organic ligands. J. Environ Qual. 4:658-663.

Giusquiani P.L., Gigliotti G. and Busunelli D.(1992). Mobility of heavy metals in urban waste-amanded soils. J. Environ. Qual., 16: 330-335.

Gove L.,Cooke C.M. , Nicholson F.A. and Beck A.J. (2001). Movement of water and heavy metals $(\mathrm{Zn}, \mathrm{Cu}, \mathrm{Pb}, \mathrm{Ni})$ through sand and sandy loam amended with biosolids under steady state hydrological conditions. Bioresource Tech., 78: 171-179.

Halim M., Conte P. and Piccolo A. (2003). Potential availability of heavy metals to phytoextraction from contaminated soils induced by exogenous humic substances. Chemosphere, 52: 265-275.

Hossner L.H. (1996). Dissolution for total elemental analysis. In: Methods of Soil Analysis. Part 3, $3^{\text {rd }}$ edition Chemical Methods. (eds.) Sparks et al. SSSA and ASA, Madison, WI. p: 46-64. 
Kabala C. and Singh B.R. (2001). Fractionation and mobility of copper, lead and $\mathrm{Zn}$ in soil profile in the vicinity of a copper smelter. J. Environ. Qual.,30 - 485 - 492.

Kashem M.A. and Singh B.R. (2002). Distribution and mobility of $\mathrm{Cd}, \mathrm{Ni}, \mathrm{Zn}$ in contaminated tropical soil profiles. $17^{\text {th }}$ WCSS, $14-21$ August2002 .Thailand . (625 -1 )- (625 -9).

Kim N.D. and Fergusson J.E.(1991). Effectiveness of commonly used sequential extraction technique in determining and speciation of cadmium in soil. Sci. Total Environ., 105: 191-209.

Lena Q.M. and Gade B.R. (1997). Chemical fractionation of cadmium, copper, nickel and zinc in contaminated soils. J. Environ. Qual., 26: $259-264$.

Lucho-Constantino C.A., Prieto-Garacia F., DelRazo L.M. Rodriguez-Vazquez R. and PoggiVaraldo H.M. (2005). Chemical fraction of boron and heavy metals in soils irrigated with wastewater in central Mexico . Agriculture, Ecosystem, and Environment, 108: 57-71.

Ma L. Q., Tan F. and Harris W. G. (1997).Concentrations and distribution of element metals in Florida soils. Journal of Environmental Quality, 26:769-775.

McBride M.B. (1995). Toxic metal accumulation from agriculture use of sludge. Journal of Environmental Quality, 24: 5-18.

McBride M.B., Richards B.K., Stenhuis T., Russo R. and Sauve S. (1997). Mobility and solubility of toxic metals and nutrients in soil fifteen years after sludge application. Soil Sci., 162: 487-500

Navas A. and Lindhorfer H. (2002). Geochemical speciation of heavy metals in sediment soils of the central Ebro Valley ( Spain ). Environ. Int., 29: 61-68.

Page A.L., Miller R.H. and Keeney D.R. (1982). Methods of Soil Analysis. No. 9 (Part 2) in the Agronomy Series. Amer. Soc. of Agron., Madison., Wisc., USA.

Pilar B., Madejon E., Mora A. P. and Cabera F. (2006). Speatial variability of the chemical characteristics of a trace - elements - contaminated soil before and after remediation. Geoderma, 130: 157 - 175.

Qiao X.L., Luo Y.M., Chistie P. and Wong M.H. (2003). Chemical speciation and extractability of $\mathrm{Zn}, \mathrm{Cu}$, and $\mathrm{Cd}$ in two contrasting biosolids-amended clay soils. Chemosphere, 50: 823-829.

Richards B.K., Stenhuis T.S., Peverly J.H. and McBride M.B. (2000). Effect of sludge processing mode, soil texture and soil $\mathrm{pH}$ on metal mobility in undisturbed soil columns under accelerated leaching. Envior. Pollu., 109: 327-346.

Robertson W. K., Lutrick M. C. and Tuan T. L. (1982). Heavy applications of liquid-digested sludge on three Ultisols: I. Effects on soil chemistry. J. Environ. Qual., 11: 278-282

Sanchez-Martin M. J. and Sanchez-Camazano M. (1993). Adsorption and mobility of cadmium in natural, uncultivated soils. J. Environ. Qual., 22:737-742.

Sloan J. J., Dowdy R. H., Dolan M. S. and Linden D. R. (1997). Long-term effects of biosolids applications on heavy metal bioavailability in agricultural soils. J. Environ. Qual.,26:966974.

Snedecor C.W. and Cochran G. (1973). Statistical Methods. Iowa State Univ., Press, USA.

Soil Survey Staff (1999). Soil Taxonomy" A Basic System of Soil Classification for Making and Interpreting Soil Surveys.". USDA. Agric.,Adric. Hand b.363, Second Edition, U.S. Gov. Print. Office, Washington, DC.

Tagwira F., Piha M. and Mugwira L. (1993). Zinc distribution in cotton using lime or mushroom compost. Soil Sci. \& Plant Analysis., 24:841861

Tania L. , Preda Mi and.Cox M.(2003). Heavy metal distribution and controlling factors within costal plain sediments Bells Creek Catchment, Southeast Queensland, Australia. Environmental International 29 : 935 - 948.

Williams D. E., Vlamis J., Pukite A.H. and Corney J.E. (1985). Metal movement in sludge-treated soils after six years of sludge additions. 2. Ni, $\mathrm{Co}, \mathrm{Fe}, \mathrm{Mn}, \mathrm{Cr}$, and $\mathrm{Hg}$. Soil Sci., 140:120-125. 
